\title{
AIRCRAFT AIR POLLUTANT EMISSIONS IN GREEK AIRPORTS
}

\section{G. TSILINGIRIDIS*}

\author{
Aristotle University of Thessaloniki \\ Department of Mechanical Engineering \\ Process Equipment Design Laboratory, P.O. Box 487 \\ GR 54124 Thessaloniki, Greece
}

Received: 27/06/08

*to whom all correspondence should be addressed:

Accepted: 24/10/08

e-mail: tsil@eng.auth.gr

\begin{abstract}
During recent years special attention has been paid to various environmental impacts from aircraft emissions. The effects become more important considering the present situation in the air traffic sector and future expectations for higher air travel demands.

In this paper the evolution of aircraft air pollutant emissions in Greek airports from 1980 to 2005 is analysed. The estimation of emissions, based on the EMEP/CORINAIR methodology, takes into account all flight categories (domestic, international, scheduled, charters) and all aircraft types used in civil aviation in Greece. Emissions are estimated for Landing and Take Off (LTO) cycles. Estimations cover 38 airports used by civil aviation and show a high increase of emissions, which followed the high increase of air traffic in all Greek airports. Total flights increased by 2.4 times from 1980 to 2006. Athens airport has the higher contribution to total air traffic, as well in total emissions, but with decreasing trend $(59.0 \%$ in $1980-42.2 \%$ in 2005). Thessaloniki and Iraklion airports follow with increasing share (6.3 - 11.7\% and 6.8 $9.8 \%$ respectively).

Changes in aircraft fleet composition together with changes of each airport contribution in total civil aviation traffic influenced the increase rates of each air pollutant. $\mathrm{NO}_{\mathrm{x}}$ emissions showed higher increase rates than air traffic, while $\mathrm{VOC}$ and $\mathrm{CO}$ emissions showed lower increase rates. Average per flight emissions from 1980 to 2005 have shown increased trend for $\mathrm{NO}_{\mathrm{x}}$, decreased trend for VOC and $\mathrm{CO}$ and almost stable per flight emissions for $\mathrm{SO}_{2}$ and $\mathrm{PM}_{2.5}$.
\end{abstract}

KEYWORDS: Air pollution, LTO, aviation, air transport, air traffic, airplane, Greece.

\section{INTRODUCTION}

Aircraft activities generate a relatively small proportion of the global emissions of most air pollutants. For example, the contribution of nitrogen oxides $\left(\mathrm{NO}_{\mathrm{x}}\right)$ from aircraft is estimated to be about $1.5 \%$ of global emissions including natural sources, while in the case of carbon dioxide $\left(\mathrm{CO}_{2}\right)$ aircraft contribute $2 \%-3 \%$ of total global anthropogenic emissions (McInnes and Walker, 1992; IPCC, 1999; Scheelhaase and Grimme, 2007). However, although aircraft activities have a relatively small contribution to overall emissions, a significant proportion of these are emitted at altitudes of about 10-12 kilometres, where in general, there are no other sources of direct emission (air pollution produced by lightning usually occurs below 8 kilometres). The effect of aircraft emissions on the chemistry of the atmosphere at such altitudes is quite different from the effect of similar amounts of pollution emitted at ground level. At ground level the effect of aircraft emissions is of major importance, since most airports are close to urban areas. Moreover, the importance of aircraft and all airport related emission source activities is growing (Schurmann et al., 2007; Peace et al., 2006; Unal et al., 2005) as the volume of air traffic is steadily increasing and forecasts for global air transport show an increase of about 150\% (average annual growth rate 4.8\%) for the period 2005 to 2025 (Scheelhaase and Grimme, 2007).

In Greece, aircraft emission in the vicinity of airports (LTO cycle) have a small contribution to 
overall emissions, as well. In the case of $\mathrm{NO}_{x}$ and NMVOC, aircraft emissions were $1.7 \%$ and $2.0 \%$ of the emissions from road traffic for the year 2002 (Tsilingiridis, 2005). These values are of the same order as in other countries: in Denmark, airport $\mathrm{NO}_{\mathrm{x}}$ emissions are $7 \%$ of the national total for the year 1998, while VOC and CO emissions are 1\% (Winther, 2001); in Turkey, $\mathrm{NO}_{\mathrm{x}}$ and $\mathrm{CO}$ airport emissions are less than $1 \%$ of the national total for the year 2001 (Kesgin, 2006). The small contribution of air traffic to overall emissions seems to be the major reason for the limited research activity, which is mainly oriented to abate noise pollution. Published work for Greece is also limited (Tsouka et al., 1989; Moussiopoulos et al., 1997; Stefanou and Haralambopoulos, 1998; Tsilingiridis et al., 1998) and most of them refer to Environmental Impact Assessment Studies for new airports or extension of the existing ones. However, air traffic is steadily increasing in Greece, too. Figure 1 shows the historical development (Hellenic Civil Aviation Authority, 2008) and forecasts for air traffic in Greek airports (total, domestic and international flights). Total flights increased by 2.4 times from 1980 to 2006, while domestic and international (scheduled and charters) flights increased by 2.7 and 2.2 times respectively. Decreases in air traffic in 1973-'74, 1980-'81, 1991 and 2001 are due to oil crises and US travel directives during the wars in Yugoslavia, Persian Gulf and Iraq. Forecasts made in the framework of the present work, are based on recent years' trend (1990-2006), and result in a 70\% increase of total, $78 \%$ of domestic and $63 \%$ of international flights, up to the year 2025. The average annual growth rate during this period was $2.5 \%$, varying from $2.8 \%$ in 2007 to $1.9 \%$ in 2025 .

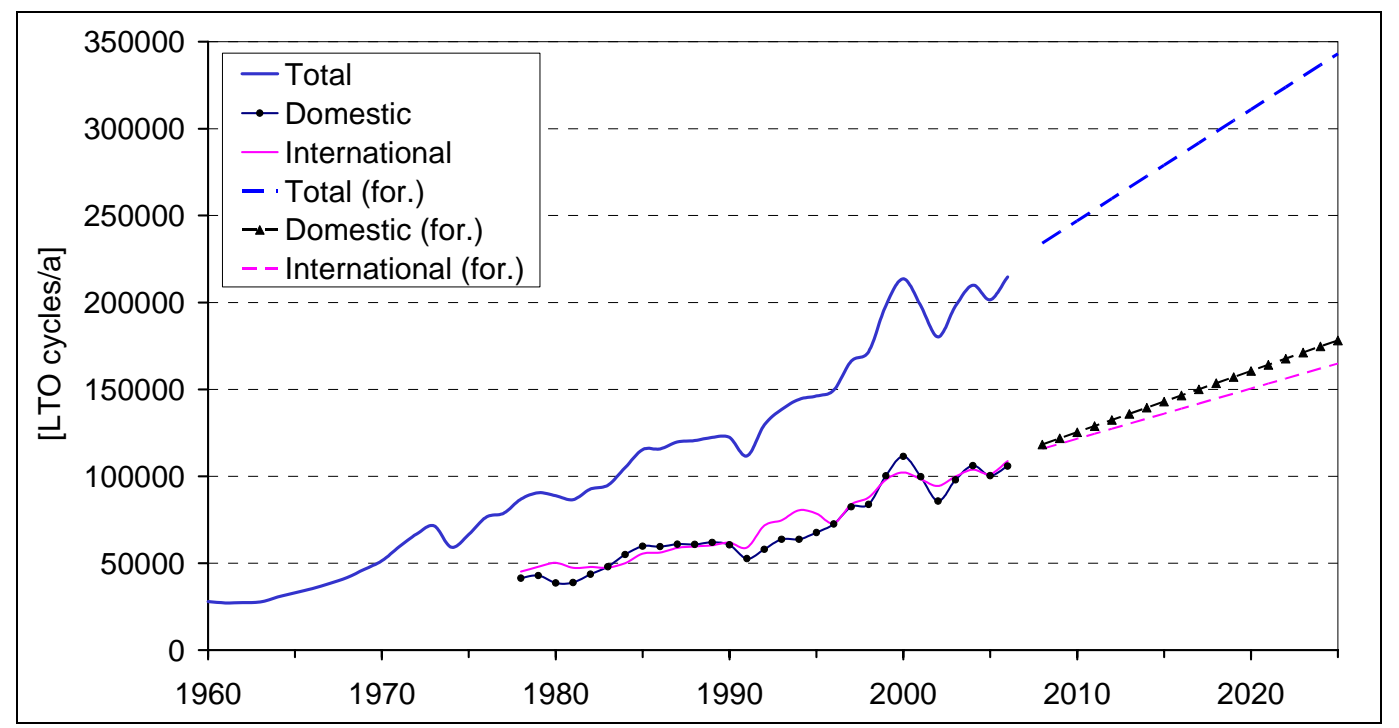

Figure 1. Historical development and forecasts of air traffic in Greece by flight category

Due to the expected significant increase of air traffic, the examination of the environmental impact of air traffic at global, national or local level is of most importance. In this paper the evolution of air pollutant emissions $\left(\mathrm{SO}_{2}, \mathrm{NO}_{\mathrm{x}}, \mathrm{CO}, \mathrm{VOC}, \mathrm{PM}\right)$ from aircraft activities in Greek airports is examined, taking into consideration both domestic and international aviation.

\section{DESCRIPTION OF AIR TRAFFIC ACTIVITIES}

Civil aviation aircraft activities include all non-military commercial and charter flights for which passenger and freight kilometres, or other activity data, are published. Military aircraft activities are excluded, although they may have a significant share to the total national emissions. That is because it is difficult to obtain all the necessary information mainly due to the confidential character of both flights and equipment. Civil helicopter activity in Greece is very limited; therefore it is also not included in this survey.

Operations of civil aviation aircraft are divided into two parts (European Environment Agency, 2007):

- The LTO cycle, which includes all activities of airplanes near the airport that take place under the altitude of $1000 \mathrm{~m}$ and comprises of the following stages: taxi-in and out, ground idle, climbing and descending. 
- Cruise, which is defined as all activities that take place at altitudes above $1000 \mathrm{~m}$.

Available statistics count landing and take-off as two separate operations (arrival and departure). However, it is both one landing and one take-off for the same aircraft that defines one LTO cycle. They also count separately national and international aviation. National aviation includes all civil passenger and freight traffic inside a country, while international aviation is all civil air traffic coming to or leaving a country. The above distinctions are independent of the nationality of the air carrier.

The characteristics of aircraft combustion emissions are different with respect to the type of fuel used, the location (altitude) of the exhaust gases, and the efficiency of the engines. Emissions come from the combustion of kerosene (jet fuel) and aviation gasoline, which are used as fuel on the aircraft.

Use of energy, and therefore emissions, is dependent on the aircraft operations and the time spent at each stage of the LTO cycle. A substantial part of the fuel consumption takes place outside the LTO cycle. Studies indicate that the major part of $\mathrm{NO}_{\mathrm{x}}(60-80 \%), \mathrm{SO}_{2}$ and $\mathrm{CO}_{2}$ $(80-90 \%)$ is emitted at altitudes above $1000 \mathrm{~m}$. For CO it is about $50 \%$ and for VOC it is $20-$ 40\% (European Environment Agency, 2007).

\section{METHODS}

For the estimation of emissions the methodology based on information per aircraft type is followed. This methodology uses the number of LTO cycles carried out with the various aircraft types and emission factors for a standard LTO cycle (European Environment Agency, 2007) and is widely used (Kim et al. 2006; Unal et al., 2005). More detailed estimations require emission factors based on all different engine types an aircraft model is equipped with and topographic characteristics of each airport (Sidiropoulos et al., 2005; Kesgin, 2006), information which is not always available.

According to the 'standard LTO cycle emission factors methodology', air pollutant emissions estimation is described by the following equation:

$$
E m_{p}=10^{-6} \times \sum_{r} E m_{r, p}=10^{-6} \times \sum_{r} \sum_{t} E F_{t, p} \times A_{r, t}
$$

where, $\quad r$ refers to the airport under consideration,

$\mathrm{t}$ refers to the specific aircraft type,

$\mathrm{p}$ refers to the specific pollutant $\left(\mathrm{SO}_{2}, \mathrm{NO}_{x}, \mathrm{VOC}, \mathrm{CO}, \mathrm{PM}\right)$,

$\mathrm{Em}_{\mathrm{p}}$ annual emissions $\left[\mathrm{t} \mathrm{y}^{-1}\right]$ of pollutant $\mathrm{p}$ from all airports,

$\mathrm{Em}_{\mathrm{r}, \mathrm{p}} \quad$ annual emissions $\left[\mathrm{g} \mathrm{y}^{-1}\right]$ of pollutant $\mathrm{p}$ in airport $\mathrm{r}$,

$E F_{t, p}$ emission factor [ $\left.g / L T O\right]$ of pollutant $p$ from aircraft type $t$,

$A_{r, t}$ annual activity level [LTO $y^{-1}$ ] from aircraft type $t$ in airport $r$.

The necessary data for the calculations are derived from:

\section{- Air traffic statistics}

In Greece, 38 civil aviation airports are in operation at present. The data used for the emission estimations originate from national statistics (Hellenic Civil Aviation Authority; National Statistical Service of Greece, 2008) providing aggregated information on the number of landings and take-offs (arrivals and departures) taking place for national and international aviation in each airport. Table 1 shows the evolution of total air traffic in Greece and in the ten airports with the highest traffic. Air traffic in 2005 had an Increase Index of 225 compared to 1980 air traffic (ref. year 1980=100).

- Aircraft fleet composition

The data used for the emission estimations are from airport authorities (Hellenic Civil Aviation Authority, 2002) providing information on the number of flights of all aircraft types in each airport. The aircraft fleet composition in Greece is given for the years 1980 and 2000 in Figure 2 and for domestic and international flights for the year 1995 in Figure 3. It can be seen that larger aircrafts, such as B737 and Airbus, have grown their share, as well as ATR, Dornier and Islander propelled (turbo-prop) aircrafts. 
- Emission factors

Emission factors for LTO cycles are given per aircraft type (European Environment Agency, 2007).

Table 1. Evolution of total air traffic (number of LTO cycles) in main Greek airports

\begin{tabular}{|r|l|r|r|r|r|r|r|}
\hline No & Airport & \multicolumn{1}{|c|}{$\mathbf{1 9 8 0}$} & \multicolumn{1}{|c|}{$\mathbf{1 9 8 5}$} & \multicolumn{1}{|c|}{$\mathbf{1 9 9 0}$} & \multicolumn{1}{|c|}{$\mathbf{1 9 9 5}$} & \multicolumn{1}{|c|}{$\mathbf{2 0 0 0}$} & \multicolumn{1}{c|}{$\mathbf{2 0 0 5}$} \\
\hline 1 & Athens & $59.0 \%$ & $50.2 \%$ & $45.9 \%$ & $41.3 \%$ & $43.6 \%$ & $42.2 \%$ \\
2 & Thessaloniki & $6.3 \%$ & $7.2 \%$ & $7.8 \%$ & $10.5 \%$ & $11.1 \%$ & $11.7 \%$ \\
3 & Iraklion & $6.8 \%$ & $7.2 \%$ & $7.2 \%$ & $9.1 \%$ & $9.8 \%$ & $9.5 \%$ \\
4 & Rhodes & $7.5 \%$ & $7.6 \%$ & $7.5 \%$ & $6.8 \%$ & $7.0 \%$ & $7.1 \%$ \\
5 & Kerkira (Corfu) & $4.8 \%$ & $4.8 \%$ & $4.6 \%$ & $4.5 \%$ & $4.0 \%$ & $3.6 \%$ \\
6 & Kos & $1.9 \%$ & $2.6 \%$ & $2.7 \%$ & $3.0 \%$ & $2.7 \%$ & $3.1 \%$ \\
8 & Chania & $1.4 \%$ & $1.5 \%$ & $2.1 \%$ & $2.5 \%$ & $3.1 \%$ & $3.2 \%$ \\
7 & Santorini & $0.6 \%$ & $1.3 \%$ & $1.5 \%$ & $2.3 \%$ & $2.2 \%$ & $1.8 \%$ \\
9 & Mikonos & $1.4 \%$ & $2.5 \%$ & $2.7 \%$ & $1.8 \%$ & $1.6 \%$ & $1.6 \%$ \\
10 & Zakinthos & $0.2 \%$ & $0.8 \%$ & $1.4 \%$ & $1.7 \%$ & $1.5 \%$ & $1.8 \%$ \\
& Rest Airports & $10.1 \%$ & $14.2 \%$ & $16.7 \%$ & $16.5 \%$ & $13.4 \%$ & $14.4 \%$ \\
\hline & Total air traffic & 89652 & 115339 & 122787 & 146183 & 210388 & 201582 \\
\hline & Increase Index & 100 & 129 & 137 & 163 & 235 & 225 \\
& (1980 = 100) & 100 & & & & \\
\hline
\end{tabular}

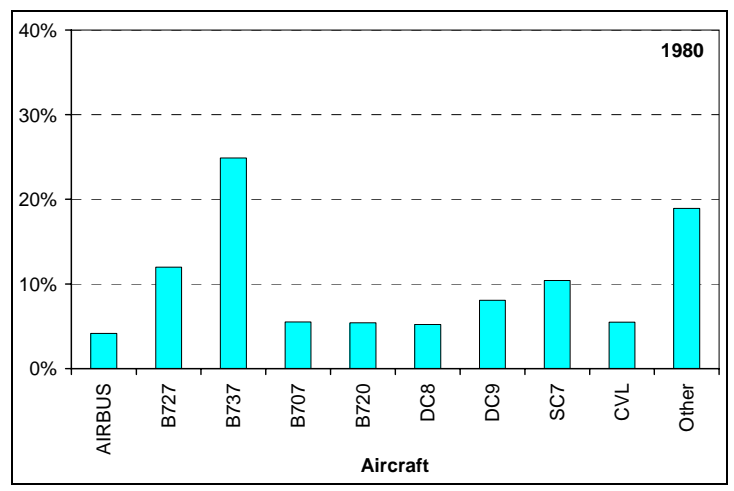

(a)

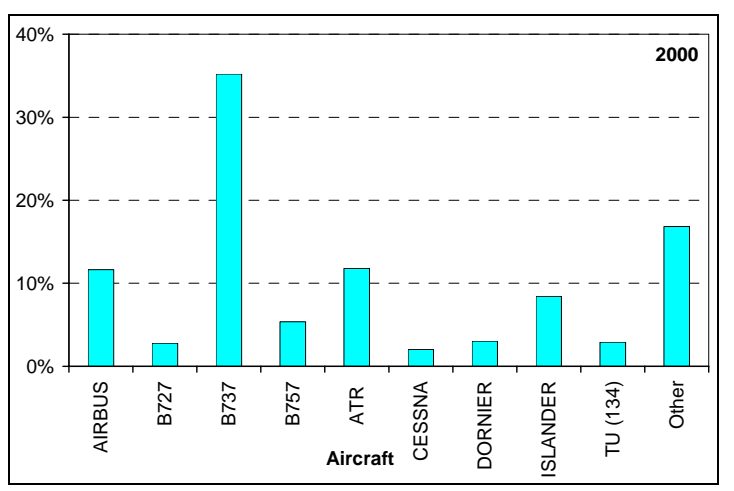

(b)

Figure 2. Aircraft fleet composition in Greece for the years (a) 1980 and (b) 2000

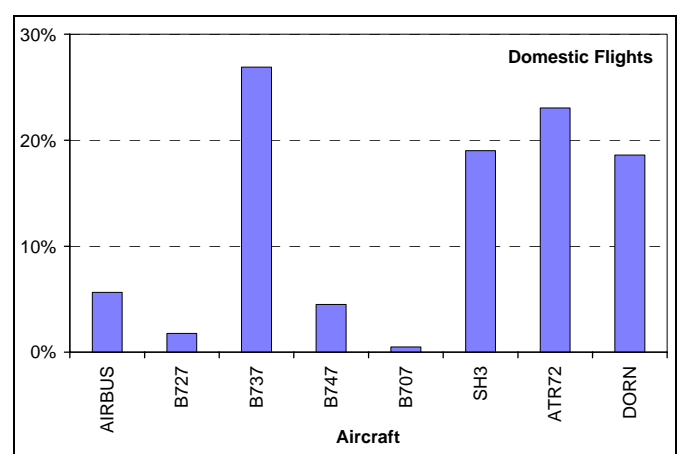

(a)

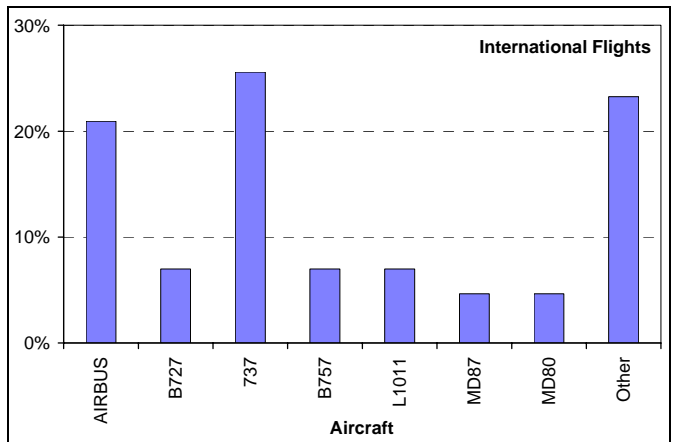

(b)

Figure 3. Aircraft fleet composition in Greece in 1995 for

(a) domestic and (b) international flights 
Table 2. Aircraft emissions in Greek airports

\begin{tabular}{|c|c|c|c|c|c|c|}
\hline Year & Airport & $\mathrm{SO}_{2}$ & $\mathrm{NO}_{\mathrm{x}}$ & VOC & CO & $\mathrm{PM}_{2.5}$ \\
\hline \multirow{12}{*}{1980} & Athens & $63.1 \%$ & $67.0 \%$ & $58.3 \%$ & $60.0 \%$ & $65.1 \%$ \\
\hline & Thessaloniki & $7.5 \%$ & $7.3 \%$ & $9.1 \%$ & $8.4 \%$ & $8.3 \%$ \\
\hline & Iraklion & $7.2 \%$ & $7.0 \%$ & $6.4 \%$ & $6.7 \%$ & $6.7 \%$ \\
\hline & Rhodes & $6.9 \%$ & $6.6 \%$ & $6.2 \%$ & $6.5 \%$ & $6.2 \%$ \\
\hline & Kerkira (Corfu) & $5.2 \%$ & $5.3 \%$ & $3.8 \%$ & $4.4 \%$ & $4.4 \%$ \\
\hline & Kos & $1.7 \%$ & $1.6 \%$ & $0.8 \%$ & $1.2 \%$ & $1.1 \%$ \\
\hline & Chania & $0.8 \%$ & $0.5 \%$ & $1.6 \%$ & $1.3 \%$ & $0.8 \%$ \\
\hline & Santorini & $0.4 \%$ & $0.2 \%$ & $0.7 \%$ & $0.6 \%$ & $0.4 \%$ \\
\hline & Mikonos & $0.8 \%$ & $0.5 \%$ & $1.5 \%$ & $1.3 \%$ & $0.8 \%$ \\
\hline & Zakinthos & $0.1 \%$ & $0.1 \%$ & $0.3 \%$ & $0.2 \%$ & $0.1 \%$ \\
\hline & Rest Airports (20) & $6.2 \%$ & $3.8 \%$ & $11.4 \%$ & $9.5 \%$ & $6.1 \%$ \\
\hline & Total Emissions [ $\left.\mathrm{t} \mathrm{y}^{-1}\right]$ & 102 & 813 & 1845 & 3132 & 56 \\
\hline \multirow{13}{*}{1995} & Athens & $42.7 \%$ & $43.7 \%$ & $55.3 \%$ & $46.8 \%$ & $37.8 \%$ \\
\hline & Thessaloniki & $12.1 \%$ & $10.9 \%$ & $14.5 \%$ & $13.1 \%$ & $17.0 \%$ \\
\hline & Iraklion & $11.3 \%$ & $11.5 \%$ & $8.3 \%$ & $9.6 \%$ & $12.8 \%$ \\
\hline & Rhodes & $8.1 \%$ & $8.4 \%$ & $5.2 \%$ & $6.0 \%$ & $8.4 \%$ \\
\hline & Kerkira (Corfu) & $5.6 \%$ & $5.8 \%$ & $4.2 \%$ & $4.4 \%$ & $6.0 \%$ \\
\hline & Kos & $3.6 \%$ & $3.7 \%$ & $2.6 \%$ & $2.8 \%$ & $3.8 \%$ \\
\hline & Chania & $2.9 \%$ & $3.1 \%$ & $1.8 \%$ & $2.2 \%$ & $3.0 \%$ \\
\hline & Santorini & $1.5 \%$ & $1.3 \%$ & $1.0 \%$ & $1.7 \%$ & $1.2 \%$ \\
\hline & Mikonos & $0.8 \%$ & $0.9 \%$ & $0.5 \%$ & $1.0 \%$ & $0.6 \%$ \\
\hline & Zakinthos & $1.8 \%$ & $2.0 \%$ & $1.5 \%$ & $1.5 \%$ & $1.9 \%$ \\
\hline & Rest Airports (28) & $9.5 \%$ & $8.7 \%$ & $5.1 \%$ & $10.9 \%$ & $7.5 \%$ \\
\hline & Total Emissions [t y $\left.{ }^{-1}\right]$ & 161 & 1328 & 2790 & 4888 & 64 \\
\hline & Increase index $(1980=100)$ & 158 & 163 & 151 & 156 & 114 \\
\hline \multirow{13}{*}{2000} & Athens & $44.3 \%$ & $47.8 \%$ & $26.3 \%$ & $36.0 \%$ & $42.5 \%$ \\
\hline & Thessaloniki & $11.7 \%$ & $10.5 \%$ & $13.8 \%$ & $12.8 \%$ & $11.6 \%$ \\
\hline & Iraklion & $11.8 \%$ & $11.0 \%$ & $16.5 \%$ & $13.7 \%$ & $12.8 \%$ \\
\hline & Rhodes & $7.9 \%$ & $7.4 \%$ & $10.9 \%$ & $9.1 \%$ & $8.3 \%$ \\
\hline & Kerkira (Corfu) & $5.1 \%$ & $4.9 \%$ & $7.9 \%$ & $6.2 \%$ & $5.8 \%$ \\
\hline & Kos & $3.6 \%$ & $3.8 \%$ & $4.4 \%$ & $3.8 \%$ & $4.1 \%$ \\
\hline & Chania & $3.8 \%$ & $3.9 \%$ & $3.7 \%$ & $3.8 \%$ & $3.8 \%$ \\
\hline & Santorini & $1.0 \%$ & $0.8 \%$ & $2.1 \%$ & $1.6 \%$ & $1.0 \%$ \\
\hline & Mikonos & $0.7 \%$ & $0.5 \%$ & $1.8 \%$ & $1.3 \%$ & $1.0 \%$ \\
\hline & Zakinthos & $1.7 \%$ & $1.6 \%$ & $2.9 \%$ & $2.1 \%$ & $1.8 \%$ \\
\hline & Rest Airports (28) & $8.4 \%$ & $7.8 \%$ & $9.7 \%$ & $9.7 \%$ & $7.1 \%$ \\
\hline & Total Emissions [t y $\left.{ }^{-1}\right]$ & 238 & 2448 & 2871 & 5833 & 137 \\
\hline & Increase index $(1980=100)$ & 233 & 301 & 175 & 186 & 245 \\
\hline \multirow{13}{*}{2005} & Athens & $43.0 \%$ & $46.5 \%$ & $25.4 \%$ & $34.9 \%$ & $41.3 \%$ \\
\hline & Thessaloniki & $12.3 \%$ & $11.1 \%$ & $14.6 \%$ & $13.5 \%$ & $12.2 \%$ \\
\hline & Iraklion & $11.4 \%$ & $10.7 \%$ & $16.0 \%$ & $13.2 \%$ & $12.5 \%$ \\
\hline & Rhodes & $7.9 \%$ & $7.4 \%$ & $10.9 \%$ & $9.1 \%$ & $8.3 \%$ \\
\hline & Kerkira (Corfu) & $4.7 \%$ & $4.5 \%$ & $7.1 \%$ & $5.6 \%$ & $5.3 \%$ \\
\hline & Kos & $4.1 \%$ & $4.3 \%$ & $5.0 \%$ & $4.3 \%$ & $4.7 \%$ \\
\hline & Chania & $4.0 \%$ & $4.1 \%$ & $3.9 \%$ & $4.0 \%$ & $4.0 \%$ \\
\hline & Santorini & $0.9 \%$ & $0.7 \%$ & $1.8 \%$ & $1.4 \%$ & $0.9 \%$ \\
\hline & Mikonos & $0.7 \%$ & $0.5 \%$ & $1.8 \%$ & $1.3 \%$ & $1.0 \%$ \\
\hline & Zakinthos & $1.9 \%$ & $1.8 \%$ & $3.2 \%$ & $2.4 \%$ & $2.1 \%$ \\
\hline & Rest Airports (28) & $9.0 \%$ & $8.4 \%$ & $10.4 \%$ & $10.4 \%$ & $7.6 \%$ \\
\hline & Total Emissions [ $\left.\mathrm{t} \mathrm{y}^{-1}\right]$ & 228 & 2339 & 2759 & 5593 & 131 \\
\hline & Increase index $(1980=100)$ & 223 & 288 & 168 & 179 & 234 \\
\hline
\end{tabular}




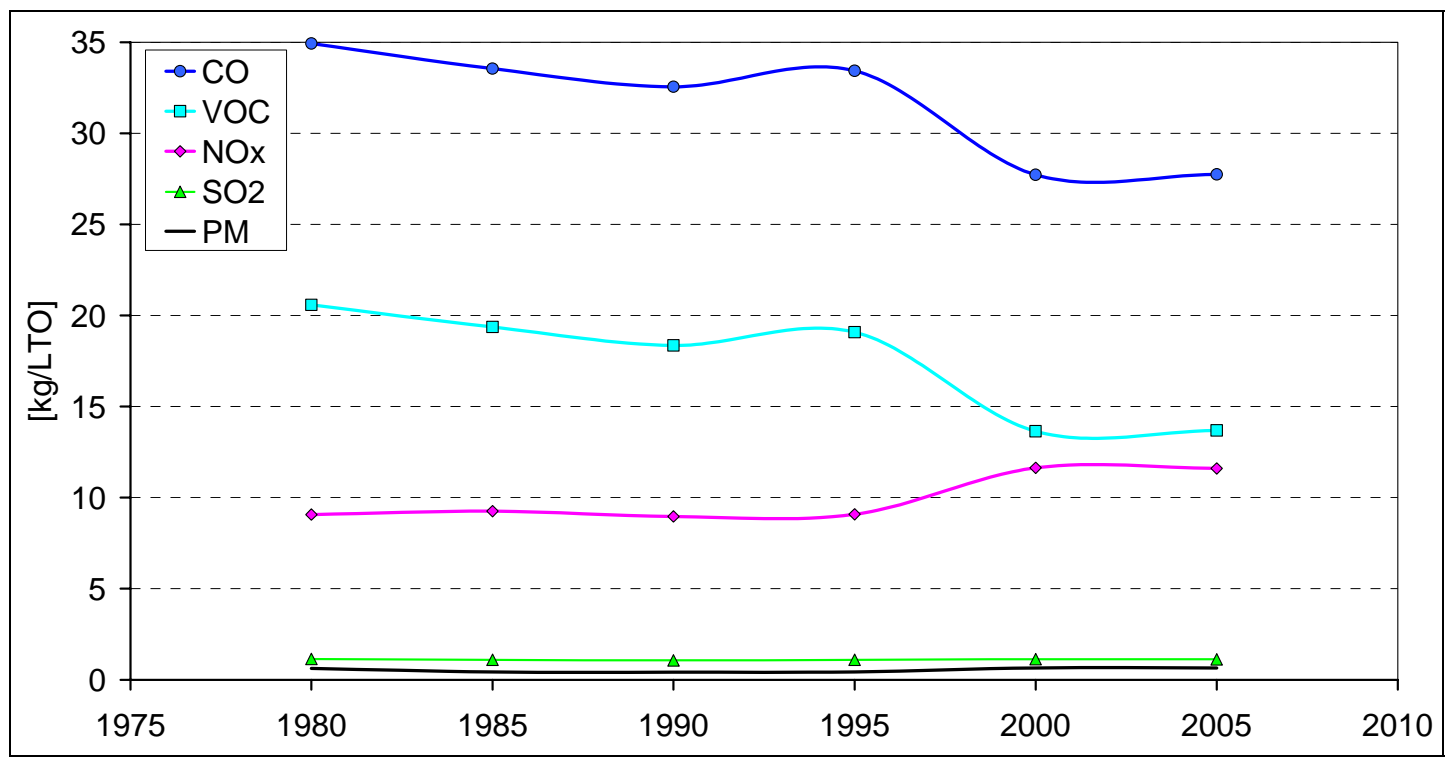

Figure 4. Evolution of average per flight emissions in Greek airports

\section{RESULTS}

Air traffic emissions for the years 1980, 1995, 2000 and 2005 in the main Greek airports are shown in Table 2, together with the values of Increase Indices of air pollutant emissions, which for 2005 are: $\mathrm{SO}_{2}=223, \mathrm{NO}_{\mathrm{x}}=288, \mathrm{VOC}=168, \mathrm{CO}=179, \mathrm{PM}_{2.5}=234$. Changes in aircraft fleet composition (Figure 2) result in higher increase rates for $\mathrm{NO}_{x}$ emissions, than increase rates of air traffic, lower for $\mathrm{VOC}$ and $\mathrm{CO}$ emissions and almost equal increase rates for $\mathrm{SO}_{2}$ and $\mathrm{PM}_{2.5}$ emissions.

The above mentioned increase rates influenced the annual average per flight emissions, which are shown in Figure 4. From 1980 to 2005 there is an increase for average $\mathrm{NO}_{\mathrm{x}}$ emissions, a decrease for $\mathrm{VOC}$ and $\mathrm{CO}$ emissions and almost stable per flight emissions for $\mathrm{SO}_{2}$ and $\mathrm{PM}_{2.5}$.

In all airports, a steady increase in air traffic and emissions was observed, but their share in total traffic (Table 1) and total emissions has changed (Table 2). Athens airport has the higher contribution to total air traffic (59.0 in $1980-41.3 \%$ in 2005), followed by Thessaloniki (6.3 $11.7 \%)$ and Iraklion airports (6.8 - 9.8\%). Athens airport decreased its contribution to total traffic as well as in total emissions, while Thessaloniki airport increased its contribution. Rest airports showed a fluctuation in their contribution.

\section{CONCLUSIONS}

The importance of aircraft emissions, as well as all other airport related emission source activities, is growing as the volume of air traffic is steadily increasing and forecasts for global air transport show an increase of about $150 \%$. Total civil aviation air traffic in Greek airports increased from 89652 in 1980 to 201582 in 2006 e.g. 2.4 times, while domestic and international (scheduled and charters) flights increased by 2.7 and 2.2 times respectively. Forecasts based on recent years' trend result in a 70\% increase of total, $78 \%$ of domestic and $63 \%$ of international flights, up to the year 2025, which means about 340000 flights in 2025.

Air traffic and related air pollutant emissions were increased in all Greek airports, but the share of each one in total has changed. Athens airport has the higher contribution to total air traffic, as well as in total emissions, but with decreasing trend (59.0 in $1980-42.2 \%$ in 2005). Thessaloniki and Iraklion airports follow with increasing share $(6.3-11.7 \%$ and $6.8-9.8 \%$ respectively). Rest airports showed a fluctuation in their contribution.

Average per flight emissions from 1980 to 2005 have shown increased trend for $\mathrm{NO}_{\mathrm{x}}$, decreased trend for $\mathrm{VOC}$ and $\mathrm{CO}$ and almost stable per flight emissions for $\mathrm{SO}_{2}$ and $\mathrm{PM}_{2.5}$. 


\section{REFERENCES}

- European Environment Agency (2007), EMEP/CORINAIR Emission Inventory Guidebook 2007, Group 8: Other Mobile Sources and Machinery, 0805 Air traffic.

- Hellenic Civil Aviation Authority, Annual Statistical Bulletin - Statistical data of Greek Airports: Years 1980 to 2000.

- Hellenic Civil Aviation Authority (2002), Statistics section, Air traffic composition data (derived electronically by personal communication).

- Hellenic Civil Aviation Authority (2008), Domestic and international air traffic statistics, http://www.ypa.gr/content/index.asp?tid=15, (accessed: Jan. 2008).

- IPCC (1999), IPCC special report: Aviation and the Global Atmosphere. Summary for policymakers. IPCC-XV/Doc. 9a.

- Kesgin U., (2006), Aircraft emissions at Turkish airports, Energy, 31, 372-384.

- Kim B.Y., Fleming G.G., Lee J.J., Waitz I.A., Clarke J.-P., Balasubramanian S., Malwitz A., Klima K., Locke M., Holsclaw C.A., Maurice L.G., Gupta L.M., (2007), System for assessing Aviation's Global Emissions (SAGE), Part 1. Model description and inventory results, Transportation Research Part D, 12, 325-346.

- Mclnnes G. and Walker C., (1992), The global distribution of aircraft air pollutant emissions, Warren Spring Laboratory Publications, ISBN 0856247316.

- Moussiopoulos N., Sahm P., Karatzas K., Papalexiou S., Karagiannidis A., (1997), Assessing the impact of the New Athens airport to urban air quality with contemporary air pollution models, Atmospheric Environment, 39(10), 1497-1511.

- National Statistical Service of Greece (2008), Statistical Data - Air Transports - Domestic and international air traffic by airport: 2005. http://www.statistics.gr/StatMenu.asp. (accessed: Jan. 2008).

- Peace H., Maughan J., Owen B. and Raper D. (2006) Identifying the contribution of different airport related sources to local urban air quality, Environmental Modelling \& Software, 21, 532-538

- Scheelhaase J. D. and Grimme W. G. (2007), Emissions trading for international aviation - an estimation of the economic impact on selected European airlines, Journal of Air Transport Management, 13, 253-263.

- Schurmann G., Schafer K., Jahn C., Hoffmann H., Bauerfeind M., Fleuti E., Rappengluck B., (2007), The impact of $\mathrm{NO}_{x}, \mathrm{CO}$ and $\mathrm{VOC}$ emissions on the air quality of Zurich airport, Atmospheric Environment, 41, 103-118.

- Sidiropoulos C., Ikonomopoulos A., Stratioti A., Tsilingiridis G., (2005), Comparison of typical LTO-Cycle emissions with aircraft engine- and airport-specific emissions for Greek airports, In: Proc. $9^{\text {th }}$ Int. Conference on Environmental Science and Technology, pp. B865-B870, ISSN 1106-5516.

- Stefanou P. and Haralambopoulos D., (1998), Energy demand and environmental pressures due to the operation of Olympic Airways in Greece, Energy, 23(2), 125-136.

- Tsilingiridis G., Petsos V. and Polatidis H., (1998), Civil aviation air pollutant emissions in Greece from 1960 to 1995, In: Proc. Int. Conf. Restoration and Protection of Environment IV, I, 404-411.

- Tsilingiridis G., (2005), Estimation and mapping of atmospheric pollution in Greece, Report to the Hellenic Ministry for the Environment, Physical Planning and Public Works, Athens. (in Greek)

- Tsouka D. and Charalambakis J. and Abakoumkin C., (1989), Airport environmental impact assessment, Technika Chronika-A, 9(4), 93-122. (in Greek)

- Unal A., Hu Y., Chang M.E., Odman M.T., Russell A.G., (2005), Airport related emissions and impacts on air quality. Application to the Atlanta International Airport, Atmospheric Environment, 39, 5787-5798.

- Winther M., (2001), 1998 fuel use and emissions for Danish IFR flights, National Environmental Research Institute, Env. Proj. No. 6282001. 